\title{
Assessing the Oral Health Awareness among the Final Year Undergraduate Nursing Students in Abha, Saudi Arabia
}

\author{
${ }^{1}$ Naheeda Asif, ${ }^{2}$ Shaik Mohammed Asif, ${ }^{3}$ Dara Balaji Gandhi Babu, ${ }^{4}$ Shefali Whagrey
}

\section{ABSTRACT}

Background and aim: Nurses have first level of contact with patients and their attendants. The services of nurses are also required in promoting the oral health knowledge among the general public. Thus, the aim of this study is to assess the oral health awareness of all the final year undergraduate nursing students in Abha, Saudi Arabia.

Materials and methods: A questionnaire based study was conducted in Abha, in which for a total of 204 final year undergraduate nursing students who gathered on the day of survey were given a self-administered questionnaire which included 26 questions and their knowledge and attitude toward dentistry was evaluated.

Statistical analysis: Data analysis was done using statistical package for social science (SPSS 12.0) software and Chisquare test was used to find the statistical significance among the variables.

Results: The results of the study indicate that the final year undergraduate nursing students have adequate basic knowledge regarding the oral cavity and the diseases pertaining to it, but they lack knowledge regarding the ideal brushing method, specialties in dentistry and their role. They have shown interest to improve their knowledge in dentistry by attending training programs and camps.

Conclusion: Nursing students have showed interest toward camps and clinical postings to improve there knowledge and serve the public. There exists a critical relationship between oral and general health, thus the education of healthcare workers and opportunities for cross-fertilization of ideas should be encouraged.

Keywords: Oral health, Knowledge, Dentistry, Nursing students, Undergraduates.

How to cite this article: Asif N, Asif SM, Babu DBG, Whagrey S. Assessing the Oral Health Awareness among the Final Year Undergraduate Nursing Students in Abha, Saudi Arabia. World J Dent 2014;5(4):213-217.

Source of support: Nil

Conflict of interest: None

1,2,4 Assistant Professor, ${ }^{3}$ Professor and Head

${ }^{1}$ Department of Periodontics, Mamata Dental College, Khammam, Andhra Pradesh, India

${ }^{2}$ Department of Oral Medicine and Radiology, King Khalid University, Abha, Saudi Arabia

${ }^{3,4}$ Department of Oral Medicine and Radiology, Panineeya Institute of Dental Science and Research Center, Hyderabad Telangana, India

Corresponding Author: Naheeda Asif, Assistant Professor Department of Periodontics, Mamata Dental College, Khammam Andhra Pradesh, India, Phone: 09885803714, e-mail: naheeda shaheen@yahoo.com

\section{INTRODUCTION}

Nursing is an important paramedical course and, it is considered as an essential supplementary branch of medicine. Nurses play a prominent role in providing health services along with the doctors. At present, their role in dentistry is negligible, as they have less training and knowledge regarding the instruments and various methods in this field of dentistry. ${ }^{1}$

However, the nurses can promote oral health awareness among the general population. Walid et al, Tetuan have suggested that oral health should receive greater importance in nursing curriculum, which would include many hands on courses on diagnosis of oral diseases. ${ }^{2}$ Rak and warren stated that a special nursing study group should be established to review the research, practice and current literature on oral care and in which the inclusion of the dental team would be essential. ${ }^{3}$ Thus, the aim of this study was to assess the oral health awareness among the final year undergraduate nursing students in Abha, Saudi Arabia.

\section{MATERIALS AND METHODS}

A questionnaire based descriptive cross-sectional study was conducted in June 2012 among Final Year Undergraduate nursing students from College of Nursing, King Khalid University, Abha, Saudi Arabia, using a convenient sampling method. The local ethics committee approved the study and informed consent from the students was obtained. The institutional ethical clearence reference number for this research is ECOR20120211. A total of 204 final year undergraduate nursing students who gathered on the day of the survey were given a self-administered questionnaire and were provided with 30 minutes of time to answer the questions. All the participants in this study were girls with a mean age of 22 years. The questionnaire included 26 questions and the answer was evaluated under four categories.

The first dimension obtained information on oral health, which includes questions, such as number of teeth in oral cavity, identification of tooth decay, gingivitis and effect of tobacco on oral health (Table 1).

The second dimension obtained information on oral hygiene practice, which includes questions, such as ideal brushing device, frequency of brushing, the technique of brushing, tongue cleansing and flossing habit (Table 2). 
Table 1: Oral health

\begin{tabular}{|c|c|c|c|c|}
\hline SI. no. & Questions & Choices & Frequency & Percentage \\
\hline 1. & How many teeth are there in the oral cavity? & $\begin{array}{l}\text { A. } 20 \\
\text { B. } 16 \\
\text { C. } 32 \\
\text { D. } 12\end{array}$ & $\begin{array}{l}8 \\
12 \\
184 \\
-\end{array}$ & $\begin{array}{l}4.1 \\
6.1 \\
89.8\end{array}$ \\
\hline 2. & How do you identify tooth decay initially? & $\begin{array}{l}\text { A. Black spot and cavity } \\
\text { B. Bleeding } \\
\text { C. Pain } \\
\text { D. Do not know }\end{array}$ & $\begin{array}{l}38 \\
54 \\
108 \\
4\end{array}$ & $\begin{array}{l}18.4 \\
26.5 \\
53.1 \\
2.0\end{array}$ \\
\hline 3. & $\begin{array}{l}\text { If there is yellow or greenish yellow color deposits } \\
\text { near the gums. What is it? }\end{array}$ & $\begin{array}{l}\text { A. Food deposits } \\
\text { B. Plaque and calculus } \\
\text { C. Do not know } \\
\text { D. Saliva }\end{array}$ & $\begin{array}{l}57 \\
119 \\
25 \\
3\end{array}$ & $\begin{array}{l}27.9 \\
58.5 \\
12.2 \\
1.4\end{array}$ \\
\hline 4. & If there is bleeding from the gums. What is it? & $\begin{array}{l}\text { A. Gums are healthy } \\
\text { B. Ulcerated } \\
\text { C. Gums are infected } \\
\text { D. Do not know }\end{array}$ & $\begin{array}{l}18 \\
49 \\
123 \\
14\end{array}$ & $\begin{array}{l}8.8 \\
23.8 \\
60.5 \\
6.9\end{array}$ \\
\hline 5. & What do you think periodontal disease is caused by? & $\begin{array}{l}\text { A. Aging } \\
\text { B. Bacteria } \\
\text { C. Plaque } \\
\text { D. Sweets and food drinks } \\
\text { E. Do not know }\end{array}$ & $\begin{array}{l}48 \\
40 \\
79 \\
15 \\
22\end{array}$ & $\begin{array}{l}23.8 \\
19.7 \\
38.7 \\
7.4 \\
10.4\end{array}$ \\
\hline 6. & What do you think periodontal disease may lead to? & $\begin{array}{l}\text { A. Abscess } \\
\text { B. Tooth loss } \\
\text { C. Gum pain } \\
\text { D. Tooth mobility } \\
\text { E. Do not know }\end{array}$ & $\begin{array}{l}28 \\
25 \\
50 \\
87 \\
14\end{array}$ & $\begin{array}{l}13.6 \\
12.3 \\
24.5 \\
42.8 \\
6.8\end{array}$ \\
\hline 7. & $\begin{array}{l}\text { According to you is there any } \\
\text { relation between oral health and general health? }\end{array}$ & $\begin{array}{l}\text { A. Yes } \\
\text { B. No }\end{array}$ & $\begin{array}{l}139 \\
65\end{array}$ & $\begin{array}{l}68.0 \\
32.0\end{array}$ \\
\hline 8. & $\begin{array}{l}\text { In hospitalized patients what is the common } \\
\text { dental complaint do you come across? }\end{array}$ & $\begin{array}{l}\text { A. Bleeding gums } \\
\text { B. Oral malodor } \\
\text { C. Ulcers }\end{array}$ & $\begin{array}{l}82 \\
82 \\
40\end{array}$ & $\begin{array}{l}40.1 \\
40.1 \\
19.8\end{array}$ \\
\hline 9. & Do you know that dietary habits affect gums? & $\begin{array}{l}\text { A. Yes } \\
\text { B. No }\end{array}$ & $\begin{array}{l}146 \\
58\end{array}$ & $\begin{array}{l}71.4 \\
28.6\end{array}$ \\
\hline 10. & $\begin{array}{l}\text { If a person is tobacco chewer what kind of } \\
\text { problems can he develop in oral cavity? }\end{array}$ & $\begin{array}{l}\text { A. Burning sensation } \\
\text { B. Mouth ulcers } \\
\text { C. Gum disease } \\
\text { D. Oral cancer }\end{array}$ & $\begin{array}{l}12 \\
42 \\
24 \\
126\end{array}$ & $\begin{array}{l}6.1 \\
20.4 \\
11.6 \\
61.9\end{array}$ \\
\hline
\end{tabular}

The third dimension obtained information on attitude toward dentist and dentistry (Table 3).

The fourth dimension obtained information on interest of students to improve knowledge by attending dental camps, and their interest toward clinical posting in dental departments (Table 4).

\section{STATISTICAL ANALYSIS}

Statistics was done using SPSS version 16.0 software (statistical package for social science Inc. Chicago, USA) software. Percentages and proportions were used for descriptive statistics. The Chi-square test was used to evaluate significant differences between proportions. The significance level was set to $\mathrm{p}$-value $<0.05$.

\section{RESULTS}

In this questionnaire based descriptive cross-sectional study, 204 final year undergraduate nursing students were present on the day of survey. All the participants in the present study were girls with a mean age of 22 years \pm 0.48986 .

\section{Oral Health}

$89.8 \%$ of students stated that there are 32 teeth in the adult oral cavity (Table 1). With reference to the identification of tooth decay $53.1 \%$ students stated that tooth decay can be identified by pain which was statistically significant ( $\mathrm{p}<0.05$ ). 58.5\% stated yellow or greenish yellow color depositions near the gums are plaque and calculus. $60.5 \%$ students stated that bleeding from the gums is due to infection and this response was statistically significant. $38.7 \%$ students stated that periodontal disease is caused due to plaque and $42.8 \%$ students stated periodontal disease might lead to tooth mobility. With reference to the questionnaire existence of any relation between oral health and general health, $68 \%$ students accepted 
Table 2: Oral hygiene practices

\begin{tabular}{|c|c|c|c|c|}
\hline Sl. no. & Questions & Choices & Frequency & Percentage \\
\hline 1. & What are the ideal materials for brushing? & $\begin{array}{l}\text { A. Tooth paste and brush } \\
\text { B. Tooth powder and brush } \\
\text { C. Tooth powder and finger } \\
\text { D. Neem stick }\end{array}$ & $\begin{array}{l}155 \\
31 \\
17 \\
1\end{array}$ & $\begin{array}{l}76.2 \\
15.0 \\
8.2 \\
0.6\end{array}$ \\
\hline 2. & $\begin{array}{l}\text { How many times should a person brush his teeth every } \\
\text { day? }\end{array}$ & $\begin{array}{l}\text { A. One time } \\
\text { B. Two times } \\
\text { C. More than } 2 \text { times } \\
\text { D. After every meal }\end{array}$ & $\begin{array}{l}8 \\
137 \\
21 \\
38\end{array}$ & $\begin{array}{l}4.1 \\
67.3 \\
10.2 \\
18.4\end{array}$ \\
\hline 3. & What kind of a tooth paste should a person use? & $\begin{array}{l}\text { A. Non-fluoridate } \\
\text { B. Fluoridated } \\
\text { C. Both the above } \\
\text { D. None of the above }\end{array}$ & $\begin{array}{l}92 \\
62 \\
29 \\
21\end{array}$ & $\begin{array}{l}44.9 \\
30.6 \\
14.3 \\
10.2\end{array}$ \\
\hline 4. & What kind of a brush should a person use? & $\begin{array}{l}\text { A. Soft } \\
\text { B. Medium } \\
\text { C. Hard }\end{array}$ & $\begin{array}{l}119 \\
76 \\
9\end{array}$ & $\begin{array}{l}58.5 \\
37.4 \\
4.1\end{array}$ \\
\hline 5. & What is the proper brushing method? & $\begin{array}{l}\text { A. Horizontal } \\
\text { B. Circular } \\
\text { C. Vertical } \\
\text { D. Both B and C }\end{array}$ & $\begin{array}{l}36 \\
136 \\
21 \\
11\end{array}$ & $\begin{array}{l}17.7 \\
66.7 \\
10.2 \\
5.4\end{array}$ \\
\hline 6. & How often a person should change his tooth brush? & $\begin{array}{l}\text { A. One month } \\
\text { B. Three months } \\
\text { C. Six months } \\
\text { D. When it is spoilt }\end{array}$ & $\begin{array}{l}44 \\
109 \\
33 \\
18\end{array}$ & $\begin{array}{l}21.8 \\
53.7 \\
16.3 \\
8.2\end{array}$ \\
\hline 7. & Do you advice a person to clean his tongue? & $\begin{array}{l}\text { A. Yes } \\
\text { B. No } \\
\text { C. Do not know }\end{array}$ & $\begin{array}{l}146 \\
33 \\
25\end{array}$ & $\begin{array}{l}71.4 \\
16.3 \\
12.3\end{array}$ \\
\hline 8. & Do you advice flossing and use of interdental brushes? & $\begin{array}{l}\text { A. Yes } \\
\text { B. No } \\
\text { C. Do not know }\end{array}$ & $\begin{array}{l}86 \\
66 \\
52\end{array}$ & $\begin{array}{l}42.2 \\
32.6 \\
25.2\end{array}$ \\
\hline
\end{tabular}

Table 3: Attitude toward dentistry and dentist

\begin{tabular}{|c|c|c|c|c|}
\hline Sl. no. & Questions & Choices & Frequency & Percentage \\
\hline 1. & $\begin{array}{l}\text { How often should a person } \\
\text { visit a dentist? }\end{array}$ & $\begin{array}{l}\text { A. Once in a year } \\
\text { B. Once in } 2 \text { years } \\
\text { C. Once in } 6 \text { months } \\
\text { D. When there is a pain }\end{array}$ & $\begin{array}{l}55 \\
33 \\
100 \\
16\end{array}$ & $\begin{array}{l}27.2 \\
16.3 \\
49.0 \\
7.5\end{array}$ \\
\hline 2. & $\begin{array}{l}\text { If a person is suffering from a } \\
\text { sudden tooth ache, what will } \\
\text { you do? }\end{array}$ & $\begin{array}{l}\text { A. Ask him to bear the pain until it subside } \\
\text { B. Advice an analgesic and refer to a nearby dentist } \\
\text { C. Refer to nearby dentist } \\
\text { D. Refer to nearby general physician }\end{array}$ & $\begin{array}{l}29 \\
79 \\
74 \\
22\end{array}$ & $\begin{array}{l}14.2 \\
38.8 \\
36.1 \\
10.9\end{array}$ \\
\hline 3. & $\begin{array}{l}\text { When a patient complaints to you } \\
\text { with sensitivity of teeth, what do } \\
\text { you suggest? }\end{array}$ & $\begin{array}{l}\text { A. Advice any commercially available } \\
\text { sensitivity tooth paste } \\
\text { B. Advice analgesics } \\
\text { C. Refer to nearby dentist }\end{array}$ & $\begin{array}{l}65 \\
40 \\
99\end{array}$ & $\begin{array}{l}32.0 \\
19.7 \\
48.3\end{array}$ \\
\hline 4. & $\begin{array}{l}\text { How many specialities are there in } \\
\text { dentistry? }\end{array}$ & $\begin{array}{l}\text { A. } 7 \\
\text { B. } 9 \\
\text { C. } 11 \\
\text { D. } 5\end{array}$ & $\begin{array}{l}27 \\
74 \\
43 \\
60\end{array}$ & $\begin{array}{l}13.4 \\
36.1 \\
21.2 \\
29.3\end{array}$ \\
\hline 5. & What does a periodontist do? & $\begin{array}{l}\text { A. Filling of teeth } \\
\text { B. Extraction of teeth } \\
\text { C. Gum treatment } \\
\text { D. Replacement of teeth }\end{array}$ & $\begin{array}{l}47 \\
76 \\
49 \\
32\end{array}$ & $\begin{array}{l}23.2 \\
37.4 \\
23.8 \\
15.6\end{array}$ \\
\hline
\end{tabular}

that, there is correlation existence between oral health and general health which was statistically significant ( $\mathrm{p}<0.05)$. In hospitalized patients, the common dental complaint the nursing students come across are bleeding gums (40\%) and oral malodor (40.1\%).
$71.4 \%$ students agreed that diet influences the health of gums which was statistically significant $(p<0.05)$. with reference to the questionnaire the effect of tobacco on oral health, $61.9 \%$ students agreed that tobacco chewing will lead to oral cancer $(\mathrm{p}<0.05)$ which was statistically significant. 
Table 4: Interest to improve knowledge

\begin{tabular}{lllll}
\hline SI. no. & Questions & Choices & Frequency & Percentage \\
\hline 1. & As a nursing graduate, do you think you & A. Yes & 133 & 65.3 \\
& should know more about oral cavity and oral & B. No & 46 & 22.4 \\
& diseases? & C. No comments & 25 & 12.3 \\
2. & Have you ever taken part in a dental camp & A. Yes & 128 & 62.6 \\
& conducted in your college? & B. No & 76 & 37.4 \\
3. & According to you, is there any need for a & A. Yes & 126 & 61.9 \\
& clinical posting in dental departments? & B. No & 78 & 38.1 \\
\hline
\end{tabular}

\section{Oral Hygiene Practice}

$76.2 \%$ of students' narrated toothpaste and toothbrush are an ideal method for brushing (Table 2). $67.3 \%$ of students stated that, a person should brush his teeth twice daily. $44.9 \%$ students have indicated non-fluoridated toothpaste and $58.5 \%$ suggested a soft bristle toothbrush as a daily usage. With reference to brushing technique, $66.7 \%$ have suggested circular motion as a proper brushing method and $53.7 \%$ suggested that an individual should change his brush once in every 3 months.

\section{Attitude toward Dentist and Dentistry}

$49.0 \%$ students stated that a person should visit a dentist every 6 months which was statistically significant $(\mathrm{p}<$ 0.05) (Table 3). $38.8 \%$ stated that they advise analgesic and refer the patient nearby dentist. $36.1 \%$ students stated that there are seven specialities in dentistry and $64.6 \%$ of the students are unaware of function of each speciality.

\section{Interest to improve Knowledge}

$65.3 \%$ students feel they should know more about oral cavity and oral disease and $62.6 \%$ students stated that they have taken part in a dental camp conducted in their college (Table 4). Majority (61.9\%) of students feel there is a need for the nurses to have clinical posting in dental department.

\section{DISCUSSION}

A cross-sectional questionnaire study was conducted among final year undergraduate nursing students in Abha, to know the levels of oral health awareness among them. Two hundred and four students were included in the study and they were provided with a questionnaire consisting of 26 questions, which were evaluated under four categories. All the participants in the study were girls and $73.5 \%$ among them were about 22 years of age.

In the present study, majority of nursing students were aware that an ideal device for tooth brushing is a toothbrush and a paste and, an individual should brush his teeth twice daily with a soft bristle brush to maintain a proper oral hygiene. The present findings are contrary to the study conducted by Nabil Al-Beruti ${ }^{4}$ where, most of the nurses were not aware about the type of toothbrush used and contents present in the toothpaste. $53.7 \%$ students suggested that every individual should change their toothbrush once in 3 months; these findings are in accordance with the study conducted by Saha et al in which they reported that the majority of the nurses changed their toothbrush every 3 months. ${ }^{5} 53.1 \%$ students in the study stated that initially tooth decay can be identified by pain. However, their knowledge regarding periodontal disease and its effect on tooth and surrounding structure was adequate. These findings are in contrary to the studies conducted by Walid et al and Rak et al who reported that nurses have adequate knowledge in identifying the dental caries, periodontal disease and oral cancer.

In the present study, majority of nursing students have accepted that there is a relation between oral health and general health and is in accordance with study conducted by Andersson $\mathrm{K}$ et al who reported that nurses were aware of impact of oral health in elderly patients. ${ }^{6}$ Similarly, Heinrichs EP, Family P stated that most nurses in their university were not aware of oral health and its affect on systemic disease. ${ }^{7}$ Coleman P stated that poor oral health in elders is been linked to general health. He emphasized that nurses and dental professionals can raise awareness and promote high standards of oral care in elderly people. ${ }^{8}$ Forty-nine percent of nursing students stated that an individual should visit dentist once in every 6 months, these findings were in accordance with studies conducted by Al-Beirut ${ }^{4}$ and Preston et al. ${ }^{9}$

Majority of the students in the present study accepted that they should know more about oral cavity and its diseases and showed enthusiasm in participation of health promotion camps. Several authors have stated that nurses have a high level of interest in updating themselves in oral care. ${ }^{10}$ However, Wardh et al ${ }^{11}$ stated that oral healthcare has been found to have low priority with nurses working in old age homes which could be due to increase in work load and time schedule.

In the present study, students feel the need of clinical posting in dental departments. Tetuan ${ }^{2}$ has suggested that, nursing schools should include oral health assess- 
ment in their curriculum. ${ }^{12}$ Ogunbodede et $\mathrm{al}^{13}$ stated that an oral health promotion module of short duration could sensitize nurses the importance of oral health and increase their knowledge on oral health and skills. ${ }^{13}$ The future of oral healthcare will require that dental schools work in conjunction with other healthcare team members to promote oral health and teach medical professionals about the relationship between oral health and general health. ${ }^{14}$ Clemmens and Kerr ${ }^{15}$ stated that the nurses are in ideal position to provide health promotion education and screening across the multitude of setting in which they work.

Gallagher and Rowe ${ }^{16}$ have stated that community nurses play an important role in the oral healthcare of society, particularly among those less likely to access dental services and there is a need to improve their knowledge regarding oral health aspects.

\section{CONCLUSION}

Nursing students have adequate knowledge in identification of oral structures and oral diseases. However, they are unaware of the technique of brushing. Most of the nursing students showed enthusiasm and interest in participation of camps and clinical postings to improve their knowledge and serve the public. Therefore, the present results support the importance of inter professional and collaborative education between medicine/nursing and dentistry. There exists a critical relationship between oral and general health, thus the education of healthcare workers and opportunities for cross-fertilization of ideas should be encouraged. Educational institutions do play a proactive role by creating interdisciplinary opportunities that will serve as the impetus for change in healthcare delivery. So, a new curriculum should be established for oral health care workers and the practitioners in providing basic knowledge and importance of maintaining a good oral hygiene.

\section{ACKNOWLEDGMENT}

The authors would like to acknowledge the deans of college of dentistry and college of nursing and the students of college of nursing for their contribution and healthy participation in the study.

\section{REFERENCES}

1. Walid EI, Nasir F, Naidoo S. Oral health knowledge, attitudes and behaviour among nursing staff in Lesotho. SADJ 2004 Aug;59(7):288,290,292.

2. Tetuan T. The role of nurse in oral health. Kans Nurse 2004 Nov-Dec;79(10):1-2.

3. Rak OS, Warren K. An assessment of the level of dental and mouth care knowledge amongst nurses working with elderly patients. Community Dent Health 1900 Sep;7(3):295-301.

4. Al-Beiruti N. Oral health behavior among a sample of school teachers, physicians and nurses in the Syrian Arab Republic. Eastern Mediterranean Health Journal 1997;3(2): 258-262.

5. Saha, et al. Oral hygiene practice and status among health care workers in private nursing homes of Davangere. J Ind Dent Assoc 2000;7(1):201.

6. Andersson K, Nordenram G, Wardh I, Berglund B. The district nurse's perception of elderly patients' oral health: a qualitative interview study. Acta Odontol Scand 2007 Jun;65(3):177-182.

7. Heinrichs EP, Famili P. Dental school faculty teaching the periodontal-systemic connection to medical students: a pilot mini-elective. J Dent Educ 2011 Oct;75(10):1370-1373.

8. Coleman P. Oppurtunities for nursing dental collaboration: adressing oral health needs among the elderly. Nurs Outlook 2005 Jan-Feb;53(1):33-39.

9. Preston AJ, Punekar S, Gosney MA. Oral care of elderly patients: nurses knowledge and views. Postgrad Med J 2000 Feb;76(892):89-91.

10. Adams R. Qualified nurses lack adequate knowledge related to oral health, resulting in inadequate oral care of patients on medical wards. J Adv Nurs 1996 Sep;24(3):552-560.

11. Wardh I, Hallberg LR, Berggren U, Andersson L, SörensenS. Oral health education for nursing personnel; experiences among specially trained oral care aides: one-year follow-up interviews with oral care aides at a nursing facility. Scand J Caring Sci 2003 Sep;17(3):250-256.

12. Spielman AI, Terry Fulmer RN, Eisenberg ES, Alfano MC. Dentistry, nursing and medicine: a comparison of core competencies. J Dent Educ 2005;69(11):1257-1271.

13. Ogunbodede EO, Rudolph MJ, Tsotsi NM, Lewis HA, Lloya JI. An oral health promotion module for the primary health care nursing course in Acornhoek, South Africa. Public Health Nurs 1999 Oct;16(5):351-358.

14. Formicola A, Valachovic RW, Chmar JE. Curriculum and clinical training in oral health for physicians and dentists: report of panel 2 of the Macy study. J Dent Educ 2008;72 (Suppl 2):73-85.

15. Clemmens DA, Kerr AR. Improving oral health in women: nurses' call to action. MCN Am J Matern Child Nurs 2008 Jan-Feb;33(1):10-14.

16. Gallagher J, Rowe J. Community nurses contribution to oral health. Br J Community Nurs 2001 Oct;6(10):526,528-534. 